\title{
Characterization of solvatomorphs of methotrexate using thermoanalytical and other techniques
}

\author{
RENU CHADHA ${ }^{1 *}$ \\ POONAM ARORA ${ }^{1}$ \\ RUPINDER KAUR ${ }^{1}$ \\ ANUPAM SAINI ${ }^{1}$ \\ MADAN LAL SINGLA ${ }^{2}$ \\ DHARAMVIR SINGH JAIN ${ }^{3}$ \\ ${ }^{1}$ University Institute of Pharmaceutical \\ Sciences, Panjab University \\ Chandigarh-160014, India \\ ${ }^{2}$ Central Scientific Instruments \\ Organization, Sector-30/C \\ Chandigarh-16003, India \\ ${ }^{3}$ Department of Chemistry \\ Panjab University, Chandigarh-160014 \\ India
}

Accepted July 6, 2009

\begin{abstract}
Identification and characterization of different forms of methotrexate were carried out by crystallization from different solvents. Five different forms of the drug were obtained. Appearance of a desolvation endotherm in the DSC accompanied by mass loss in TGA for forms I, II, IV and V showed these forms to be acetonitrile solvate hydrate (form I), trihydrate (forms II and IV) and dimethylformamide solvate (form V), respectively. However, the desolvation peak was absent in form III (obtained from methanol) indicating the absence of any solvent of crystallization. This form was found to be partially crystalline by its XRPD pattern. Solution calorimetry was further used to differentiate between the forms as they differ in lattice energy, resulting in different enthalpies of solution. The dissolution and solubility profiles were correlated with the enthalpy of solution and subsequently with crystallinity of all the forms; the least endothermic form (form III) had the highest dissolution rate.
\end{abstract}

Keywords: solvatomorph, pseudopolymorph, methotrexate, enthalpy of solution, solution calorimetry, desolvation, dissolution rate

Investigation of polymorphism and solvatomorphism in drug molecules is an important step in any pre-formulation program from both biopharmaceutical and technological point of view $(1,2)$. It is well known that polymorphs are different crystalline forms of the same compound whereas the inclusion of a solvent in a crystal lattice gives rise to pseudopolymorphs or solvatomorphs (2). One of the most relevant features among polymorphic modifications is the difference in their solubility and dissolution rate that affect their bioavailability (3-5).

In crystal hydrates/solvates, the combination of intermolecular forces (hydrogen bonding) and crystal packing can produce very strong solvent-solid interactions leading to completely new properties in the solid state $(6,7)$. Some stable solvatomorphs require vigorous conditions for desolvation before melting, while others lose the solvent of crys-

* Correspondence; e-mail: renukchadha@rediffmail.com 
R. Chadha et al.: Characterization of solvatomorphs of methotrexate using thermoanalytical and other techniques, Acta Pharm. $\mathbf{5 9}$ (2009) 245-247.

tallization under much milder conditions and are converted to the amorphous form after desolvation.

Methotrexate, N-\{4-[(2,4-diaminopteridin-6-yl-methyl)methylamino]benzoyl\}-L-glutamic acid, introduced in 1953 as an anti-tumor agent, exerts its effect by inhibiting the enzyme dihydrofolate reductase (DHFR) and has a broad spectrum clinical activity (8). It is still the most widely used antifolate drug in spite of frequent development of resistance by various mechanisms.

Literature indicates that not much work has been done on the characterization of crystal forms of the drug except for one study in which the authors reports that the drug exists in four different types of solid forms (9). The present study primarily deals with the screening of possible crystal forms of methotrexate by solvent-mediated transformation. Given sufficient time, various forms crystallize from a supersaturated solution in order to establish equilibrium (10).

Sensitive analytical methods such as differential scanning calorimetry, powder X-ray diffraction, Fourier transform infrared spectroscopy and scanning electron microscopy have been used to characterize the various forms (11-17). Above all, much attention has been paid to utilization of the solution calorimeter, which generates data by dissolving a solid compound into a solvent, providing the enthalpy of solution which is a direct reflection of its lattice energy. As polymorphs/solvatomorphs are solid compounds that are identical chemically and differ only in crystal structure, solution calorimetry is the most suitable method for differentiation among the various crystal forms and can be correlated quantitatively with crystallinity as well as the dissolution profile.

\section{EXPERIMENTAL}

Methotrexate samples were provided by GlaxoSmithKline Pharmaceuticals Ltd., India. All solvents used in the study were of analytical grade. The buffer used for the enthalpy of solution and solubility studies was disodium hydrogenphosphate buffer (pH 7) (18).

\section{Preparation of polymorphs}

The various solvates of methotrexate were named according to the order in which they were prepared in the laboratory. Five forms were obtained in addition to the commercial drug sample. These forms were characterized using DSC, TGA, FTIR, XRPD, calorimeter and dissolution studies.

Form I was obtained by crystallization in a hot mixture of acetonitrile and water (50:50). The solution was slowly cooled to room temperature and the crystals obtained were collected by filtration. These were dried under vacuum to remove traces of the solvent and were finally stored in an airtight container.

Forms II and V were obtained when hot water was added to a saturated solution of the drug in DMSO and DMF, respectively, at room temperature. The crystals thus obtained were separated by filtration and dried as described for form I. 
R. Chadha et al.: Characterization of solvatomorphs of methotrexate using thermoanalytical and other techniques, Acta Pharm. 59 (2009) 245-247.

Form III was obtained by completely evaporating the solvent under vacuum from a solution of the drug in methanol, and form IV was directly crystallized from hot water. The solutions were allowed to stand at room temperature until sufficient crystals were formed. The procedure described above was followed for drying the crystals.

\section{Characterization of polymorphs}

Differential scanning calorimetry (DSC). - DSC thermograms of methotrexate and its forms were obtained on a Mettler Toledo DSC (Switzerland). The calorimeter was calibrated for temperature and heat flow accuracy using pure indium melting (m.p. $156.6^{\circ} \mathrm{C}$ and $\Delta H=25.45 \mathrm{~J} \mathrm{~g}^{-1}$ ). The temperature range was from $50-350{ }^{\circ} \mathrm{C}$ with a heating rate of

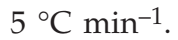

Thermal gravimetric analysis (TGA). - TGA of methotrexate and its forms was performed using a Mettler Toledo $851^{\mathrm{e}}$ TGA/SDTA. Nitrogen was used as purge gas and the heating rate was kept constant at $5{ }^{\circ} \mathrm{C} \mathrm{min}^{-1}$.

$X$-Ray powder diffraction (XRPD). - Powder diffraction patterns of methotrexate and its forms were recorded on an X-ray diffractometer (PW 1710 X-ray generator Phillips, The Netherlands) with $\mathrm{Cu}$ as tube anode. Diffractograms were recorded under the following conditions: voltage $35 \mathrm{kV}, 20 \mathrm{~mA}$, angular range 5, divergence slit 10, receiving slit $0.15 \mathrm{~mm}$.

Fourier transform infrared spectrometry (FT-IR). - The FT-IR spectra of methotrexate and its different forms were obtained on an FT-IR spectrometer, Mode spectrum RXI, Perkin Elmer (UK) over the range $400-4000 \mathrm{~cm}^{-1}$. Dry KBr $(500 \mathrm{mg})$ was finely ground in a mortar and the drug sample or its modification (1-2 mg) was subsequently added and gently mixed in order to avoid trituration of the crystals. A manual press was used to form pellets.

Enthalpy of solution. - Isoperibol solution calorimeter Model 4300 (Calorimetry Science Corporation, USA) was used to determine the enthalpy of solution of the drug and its different crystal forms. The apparatus consists of a constant temperature bath held at $37^{\circ} \mathrm{C}\left( \pm 0.005^{\circ} \mathrm{C}\right)$ and a heater assembly. The reaction vessel is a $25-\mathrm{mL}$ silvered Dewar flask. The drug was filled into a $0.9-\mathrm{mL}$ batch adaptor, sealed on both sides with 'O' rings and cover glasses. The batch adaptor holding the drug was inserted into the Dewar flask containing the buffer. The glass stirrer was rotated at 100 revolutions $\mathrm{min}^{-1}$ and was allowed to equilibrate for $90 \mathrm{~min}$. The ampoule was shattered using a plunger and the temperature change was noted. The performance of the system was checked using $\mathrm{KCl}$, which has a known enthalpy of solution and good agreement $\left( \pm 0.03 \mathrm{~kJ} \mathrm{~mol}^{-1}\right)$ was found with the published value (19).

Scanning electron microscopy. - SEM photographs of each polymorph were taken using a Jeol JSM-6100 scanning microscope (Japan) after sputtering the selected crystals with gold.

Dissolution studies. - The drug and other forms were compressed into pellets by applying a force of 10 tons for $45 \mathrm{~s}$ to provide a uniform surface for dissolution. Dissolution studies were performed using a USP paddle apparatus-12 (20) equipped with a pad- 
R. Chadha et al.: Characterization of solvatomorphs of methotrexate using thermoanalytical and other techniques, Acta Pharm. $\mathbf{5 9}$ (2009) 245-247.

dles rotating at $50 \mathrm{rpm}$ in $900 \mathrm{~mL}$ of $0.1 \mathrm{~mol} \mathrm{~L}-1 \mathrm{HCl}$ pre-equilibrated to $37 \pm 0.5^{\circ} \mathrm{C}$. The samples were withdrawn and analyzed at time intervals of 5, 10, 15, 25, 35, 45, 75, 105 minutes and then every $60 \mathrm{~min}$ till the absorbance of the solution became constant. Each dissolution study was performed on duplicate batches.

\section{RESULTS AND DISSCUSSION}

\section{DSC and TG analysis}

Initially, the DSC technique (Fig. 1) was used to find out whether a particular form was a polymorph or solvatomorph (solvates or hydrates). The commercial sample obtained revealed a DSC event peaking at $87.65{ }^{\circ} \mathrm{C}$ with a mass loss of $11.11 \%$. Calculations showed it to be a trihydrate. Further, DSC and TGA studies showed the desolvation endotherm in the temperature range between 75 and $150{ }^{\circ} \mathrm{C}$ for all forms except for form III (obtained from methanol). There was no transition corresponding to the melting endotherm but a broad peak due to decomposition was obtained for all the forms including the commercial sample. The DSC thermogram of form I (Fig. 1b) obtained from acetonitrile and water (50:50) shows an endothermic event (range 76.02 to $110{ }^{\circ} \mathrm{C}$ ) peaking at $91.82{ }^{\circ} \mathrm{C}$ which corresponds to desolvation. The TGA mass loss of $10.94 \%$ was found to be closer to that calculated (11.5\%) on the basis of 1:1:1 stoichiometry (drug/ acetonitrile/water). Thus, form I is an acetonitrile solvate hydrate. The existence of a mixed solvate with a single desolvation peak has also been reported in the literature (15).

The DSC thermogram of form II obtained from DMSO and water (Fig. 1c) also showed a dehydration endotherm at $91.72{ }^{\circ} \mathrm{C}$ (range 78.32 to $115{ }^{\circ} \mathrm{C}$ ); the corresponding TGA experiment revealed a mass loss of $11.22 \%$. Very low desolvation temperature compared to the boiling point of DMSO $\left(189{ }^{\circ} \mathrm{C}\right)$ ruled out that it was a mixed solvate. The mass loss calculation showed it to be a trihydrate (calculated $10.62 \%$ ).

Form III obtained from methanol (Fig. 1d) showed no endothermic peak corresponding to desolvation. Moreover, the decomposition peak was broad at $247.20^{\circ} \mathrm{C}$, showing this form to be partially crystalline. Form IV (Fig. 1e) obtained from water showed mass loss of $11.26 \%$ at $91.82{ }^{\circ} \mathrm{C}$, which indicates it was a trihydrate. The literature has shown the existence of trihydrates (9) as well as tetrahydrates (21) of methotrexate. The formation of a tetrahydrate in the study done by Sutton et al. (21) may be due to the fact that the glutamate side chain disorder in the molecule imparts disorder to the solvent molecules leading to a variable number of water molecules per unit cell, ranging from 2 to 4 (22).

Form V (Fig. 1f) obtained from DMF and water showed a desolvation endotherm at $120{ }^{\circ} \mathrm{C}$ with mass loss of $16.50 \%$ (calculated $16.79 \%$ ), showing form $\mathrm{V}$ to be a mixed solvate of DMF and water with the stoichiometry of 1:1:1 (15).

The inspection of DSC plots in all the solvates indicated the presence of a very small but broad endothermic depression in all the solvates and hydrates between $75-150{ }^{\circ} \mathrm{C}$. Besides, prior to decomposition there was a small endotherm in all the forms (except form III) which can be attributed to the solid-solid transition. 
R. Chadha et al.: Characterization of solvatomorphs of methotrexate using thermoanalytical and other techniques, Acta Pharm. 59 (2009) 245-247.

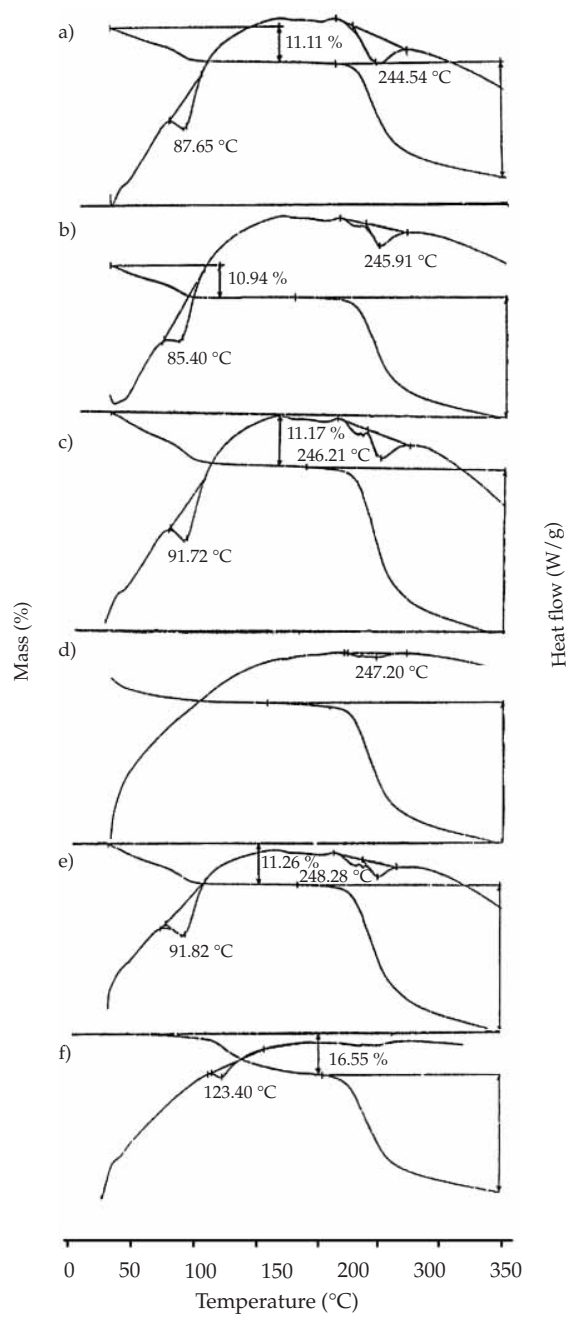

Fig. 1. DSC-TGA plots of: a) commercial methotrexate, b) form I, c) form II, d) form III, e) form IV, f) form V.

The binding strength for water and solvents $(15,16,23)$ was also calculated for all the forms (Table I) from the equation:

$$
\Delta H_{\mathrm{S}}=\left[\left(\Delta H_{\mathrm{Sexp}} \times 100\right) / \Delta m_{\mathrm{S}} \%\right] \times M_{\mathrm{S}}
$$

where $\Delta H_{\mathrm{S}}\left(\mathrm{J} \mathrm{mol}^{-1}\right)$ is the heat of vapourization of methotrexate bound solvent, $M_{S}$ is the molecular mass of the solvent, $\Delta H_{\operatorname{Sexp}}\left(\mathrm{J} \mathrm{g}^{-1}\right)$ is the enthalpy of desolvation, $\Delta m_{\mathrm{S}} \%$ is the percentage mass loss. 
R. Chadha et al:: Characterization of solvatomorphs of methotrexate using thermoanalytical and other techniques, Acta Pharm. 59 (2009) 245-247.

Table I. TGA and DSC data for the commercial sample of methotrexate and its forms

\begin{tabular}{|c|c|c|c|c|}
\hline \multirow[b]{2}{*}{ Solvate } & \multirow{2}{*}{$\begin{array}{c}\text { Mass loss, } \\
\Delta m_{\mathrm{S}}(\%)\end{array}$} & \multirow{2}{*}{$\begin{array}{c}\text { Desolvation } \\
\text { enthalpy change, } \\
\Delta H_{\text {Sexp }}\left(\mathrm{J} \mathrm{g}^{-1}\right)\end{array}$} & \multicolumn{2}{|c|}{ Heat of vaporization of solven } \\
\hline & & & $\begin{array}{c}\text { Bound, } \Delta H_{\mathrm{s}} \\
\left(\mathrm{kJ} \mathrm{mol}^{-1}\right)\end{array}$ & $\begin{array}{c}\text { Pure, } \Delta H_{\mathrm{PS}} \\
\left(\mathrm{kJ} \mathrm{mol}{ }^{-1}\right)\end{array}$ \\
\hline Commercial sample $\left(\mathrm{Mt} \times 3 \mathrm{H}_{2} \mathrm{O}\right)$ & 11.11 & 127.48 & 20.67 & 40.67 \\
\hline Form I $\left(\mathrm{M} \times \mathrm{CH}_{3} \mathrm{CN} \times \mathrm{H}_{2} \mathrm{O}\right)$ & 10.94 & 65.58 & 35.37 & 33.22 \\
\hline Form II $\left(\mathrm{Mt} \times 3 \mathrm{H}_{2} \mathrm{O}\right)$ & 11.27 & 126.97 & 20.29 & 40.67 \\
\hline Form IV $\left(\mathrm{Mt}_{3} \mathrm{H}_{2} \mathrm{O}\right)$ & 11.27 & 126.97 & 20.29 & 40.677 \\
\hline Form $\mathrm{V}\left(\mathrm{Mt} \times \mathrm{DMF} \times \mathrm{H}_{2} \mathrm{O}\right)$ & 16.55 & 90.32 & 49.71 & 46.89 \\
\hline
\end{tabular}

Mt - methotrexate

Table I shows that water molecules are not tightly bound in the crystals of methotrexate. However, stronger interaction with methotrexate host is noted for DMF and acetonitrile.

The TG results show $16.5 \%$ loss for form V due to desolvation. Forms II, IV and commercial samples are all trihydrates and show desolvation losses between 11.11 and $11.27 \%$. Form I, as already explained, is a mixed solvatomorph of acetonitrile and water.

\section{FT-IR spectroscopy}

The strong absorption band at $1750-1600 \mathrm{~cm}^{-1}$ assigned to $>\mathrm{C}=\mathrm{O}$ stretching partially overlaps with the $>\mathrm{N}-\mathrm{H}$ band which appears in the range $1640-1620 \mathrm{~cm}^{-1}$, making $>\mathrm{C}=\mathrm{O}$ stretch appear as a doublet in the commercial sample $\left(1645.8 / 1605.0 \mathrm{~cm}^{-1}\right)$ at $1645.7 / 1603.0$ and $1646.3 / 1602.8 \mathrm{~cm}^{-1}$ for forms II and IV, respectively (Fig. 2). However, in form I, small kinks appear along with the doublet, which is not very sharp. In form III, the doublet appeared at $1641.5 / 1605.7 \mathrm{~cm}^{-1}$. In the case of form $\mathrm{V}$, the number of absorption bands around this region increased, making this form the different from others. Besides, there were some observable changes from 3300 to $3400 \mathrm{~cm}^{-1}$ where the band for $-\mathrm{OH}$ and $>\mathrm{N}-\mathrm{H}$ stretching can be found. The FTIR spectra of the commercial sample, form II and form IV showed the appearance of a broad peak for $\mathrm{NH} / \mathrm{OH}$ stretching around $3300 \mathrm{~cm}^{-1}$ along with small merged peaks around $3000 \mathrm{~cm}^{-1}$ corresponding to -C-H stretch, while for form III a small doublet at $3332.4 / 3157.9 \mathrm{~cm}^{-1}$ appeared in this region. No major change in the peaks from the $-\mathrm{OH}$ region appeared for form I. However, the form $\mathrm{V}$ spectrum differed from other samples in having sharp peaks at 3466.0, $3339.1,3227.3$ and $3090.6 \mathrm{~cm}^{-1}$ instead of a broad peak.

\section{$X R P D$}

The XRPD patterns for the commercial trihydrate sample as well as for form II (obtained from DMSO + water) and for form IV (obtained from water) were similar and could be classified as isomorphic. However, the extent of crystallinity varied among these forms (Fig. 3). Also, the position of the peak corresponding to $100 \%$ intensity was different; it was located at $2 \theta$ of $26.92^{\circ}$ in the commercial sample, at $2 \theta$ of $9.41^{\circ}$ in form 


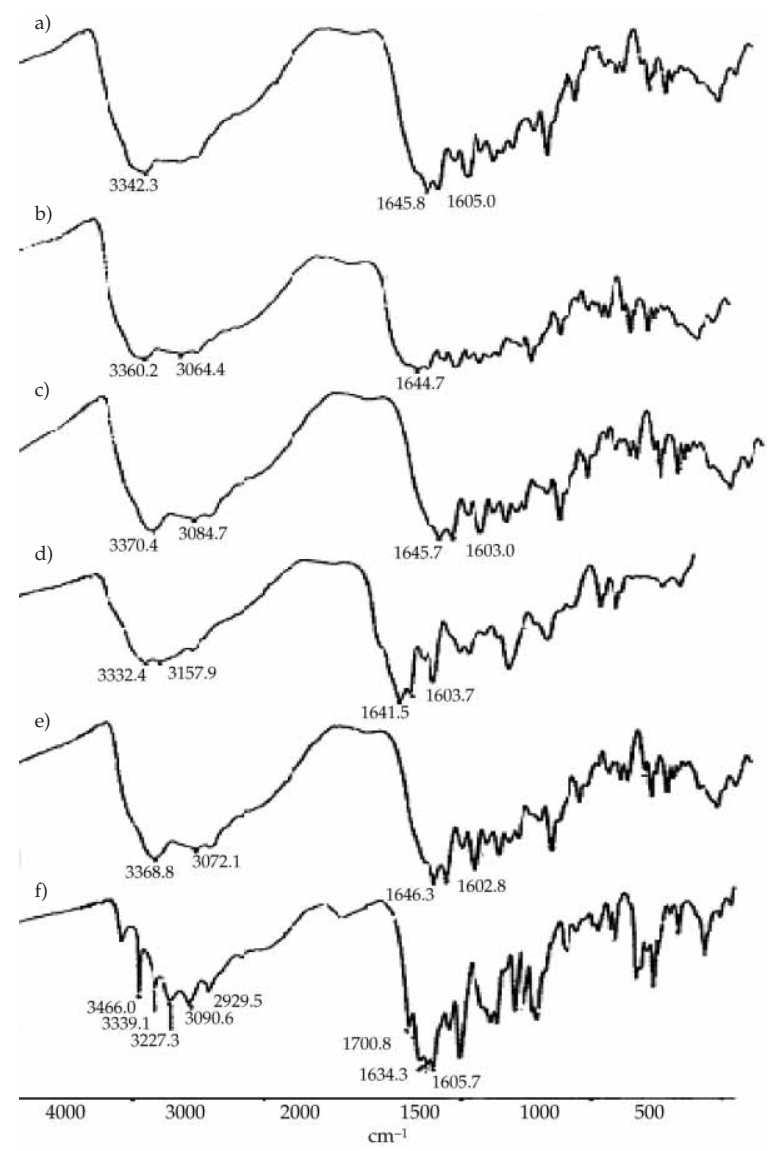

Fig. 2. FTIR Spectra of: a) commercial methotrexate, b) form I, c) form II, d) form III, e) form IV, f) form V.

II, at $2 \theta$ of $27.01^{\circ}$ in form IV. The deviation in the relative intensity might be accounted for by some preferred orientation in the sample (15). The XRPD pattern for forms I and $\mathrm{V}$ was definitely different, showing that they crystallized in a distinctly different arrangement. In form I, the peak corresponding to $100 \%$ intensity appeared at $2 \theta$ of $23.3^{\circ}$. Form III obtained from methanol appeared to be least crystalline among all the forms.

\section{Enthalpy of solution}

Polymorphs or solvatomorphs differ in their crystal structures and their individual heats of solution depend upon the solvent used for enthalpy measurement. The difference in the heat of solution of different polymorphs/solvatomorphs of a drug is independent of the solvent used and will be equal to the difference in lattice energy of the solids. 


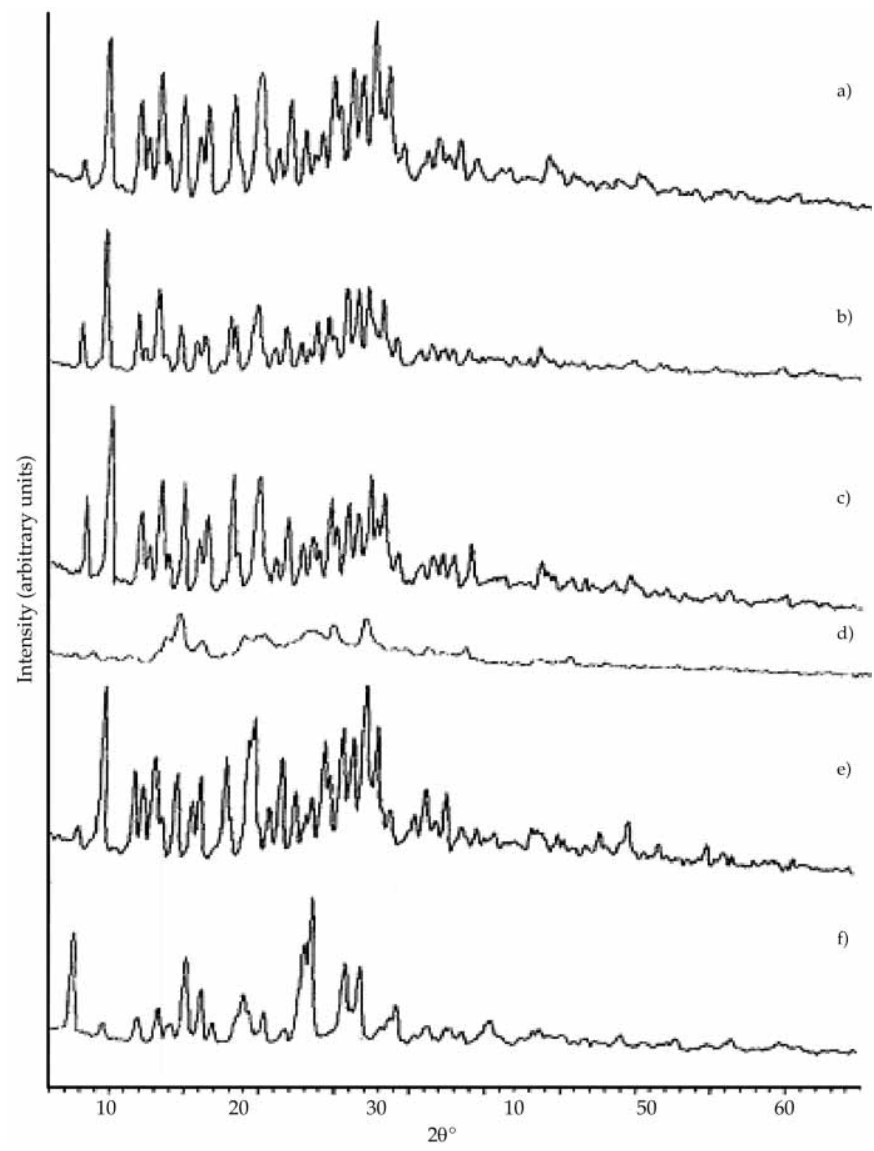

Fig. 3. XRPD patterns of: a) commercial methotrexate, b) form I, c) form II, d) form III, e) form IV, f) form $\mathrm{V}$.

Heat of solution of all crystalline forms in the buffer of $\mathrm{pH} 7$ as well as in ethanol was determined using an isoperibol solution calorimeter and the representative graph for the enthalpy of solution of form I is given in Fig. 4. All the forms, including the commercial sample, showed endothermic behavior. As expected, the absolute values varied from 15.20 to $25.78 \mathrm{~kJ} \mathrm{~mol}^{-1}$ at $\mathrm{pH} 7$ and from $10.33-20.85 \mathrm{~kJ} \mathrm{~mol}^{-1}$ in ethanol (Table II). Moreover, the heat of solution for all the forms is less endothermic in ethanol. Form III exhibited the least endothermic behavior in both solvents. This form is partially crystalline, as shown by the XRPD study, characterized by a lack of any long range crystal structure and is the least ordered phase. A more disordered phase would give rise to low enthalpy of solution considering the weaker intermolecular interaction in this phase. Form I obtained from acetonitrile and water exhibited the highest endothermic effect, indicating it was the most ordered form, which is responsible for its higher degree of crystallinity. Heat of solution and dissolution are very well correlated on the basis of Gibb's 
R. Chadha et al.: Characterization of solvatomorphs of methotrexate using thermoanalytical and other techniques, Acta Pharm. 59 (2009) 245-247.

Table II. Molar enthalpy of solution ( $\mathrm{kJ} \mathrm{mol}^{-1}$ ) in phosphate buffer ( $\mathrm{pH} 7$ )/ethanol and solubility of the commercial sample of methotrexate and its forms in phosphate buffer ( $p H 7)$

\begin{tabular}{|c|c|c|c|}
\hline \multirow{2}{*}{ Solvate } & \multicolumn{2}{|c|}{ Molar enthalpy of solution $\left(\mathrm{kJ} \mathrm{mol}^{-1}\right)$ in } & \multirow{2}{*}{$\begin{array}{c}\text { Solubility in buffer } \\
\text { pH } 7 \text { (mg per } 100 \mathrm{~mL} \text { ) }\end{array}$} \\
\hline & phosphate buffer (pH 7) & ethanol & \\
\hline Commercial sample $\left(\mathrm{Mt} \times 3 \mathrm{H}_{2} \mathrm{O}\right)$ & 21.69 & 16.82 & 567.98 \\
\hline Form I $\left(\mathrm{Mt} \times \mathrm{CH}_{3} \mathrm{CN} \times \mathrm{H}_{2} \mathrm{O}\right)$ & 25.78 & 20.85 & 448.12 \\
\hline Form II $\left(\mathrm{Mt} \times 3 \mathrm{H}_{2} \mathrm{O}\right)$ & 21.96 & 17.12 & 571.81 \\
\hline Form III (amorphous) & 15.20 & 10.33 & 759.16 \\
\hline Form IV $\left(\mathrm{Mt} \times 3 \mathrm{H}_{2} \mathrm{O}\right)$ & 21.15 & 16.32 & 581.24 \\
\hline Form V $\left(\mathrm{Mt} \times \mathrm{DMF} \times \mathrm{H}_{2} \mathrm{O}\right)$ & 23.48 & 18.73 & 538.63 \\
\hline
\end{tabular}

Mt - methotrexate

free energy and Noyes-Whitney equation (24). This approach has also been used by various researchers to investigate the polymorphs of enalapril and terfinadine $(16,25)$.

\section{SEM}

By close visual inspection of the crystal forms, definite differences in morphology were evident in the drug and its different forms (Fig. 5). The differences were confirmed by studying the shape and appearance of crystal forms with scanning electron microscopy. The differences in the morphology of various forms arose from the difference in

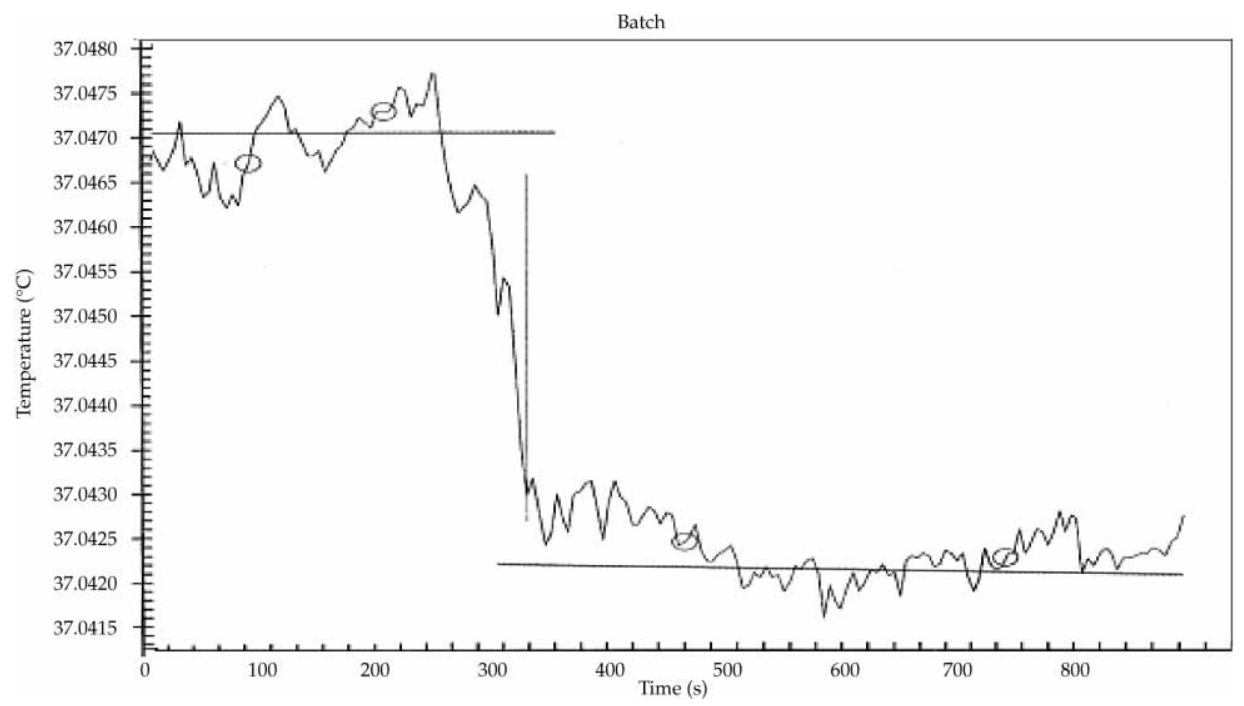

Fig. 4. Representative graph of the enthalpy of solution of form I determined using the isoperibol solution calorimeter. 


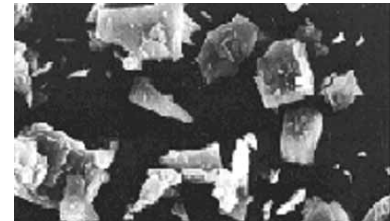

(a)

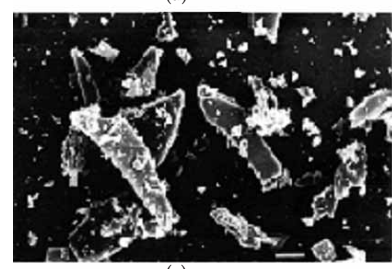

(c)

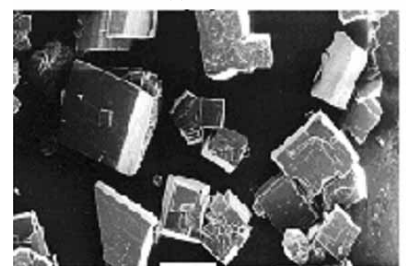

(e)

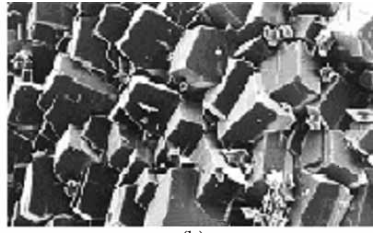

(b)

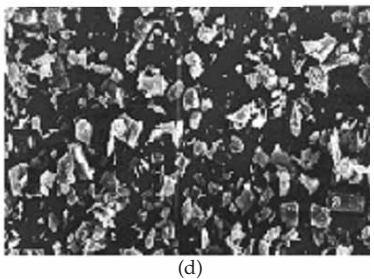

(d)

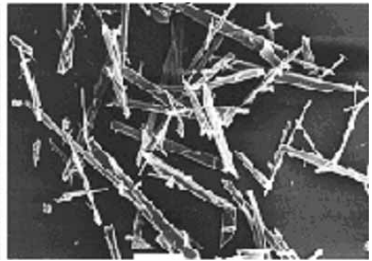

(f)
Fig. 5. Scanning electron micrographs of: a) commercial methotrexate, b) form I, c) form II, d) form III, e) form IV, f) form V.

environmental conditions under which crystals were developed. The commercial sample displayed a reticulated lattice, consisting of small crystals whereas form II obtained from DMSO exhibited a lamellar crystal habit, forming thin scales, or plates, resembling gills or lamellar. Form III had no well defined crystals, showing it to be partially crystalline. Form IV had a striated crystal habit, which displayed shallow parallel grooves or lines along flat crystal faces. Form $\mathrm{V}$ displayed an acicular crystal habit, having typically long and narrow crystal-like pine leaves and possessed a sharp point.

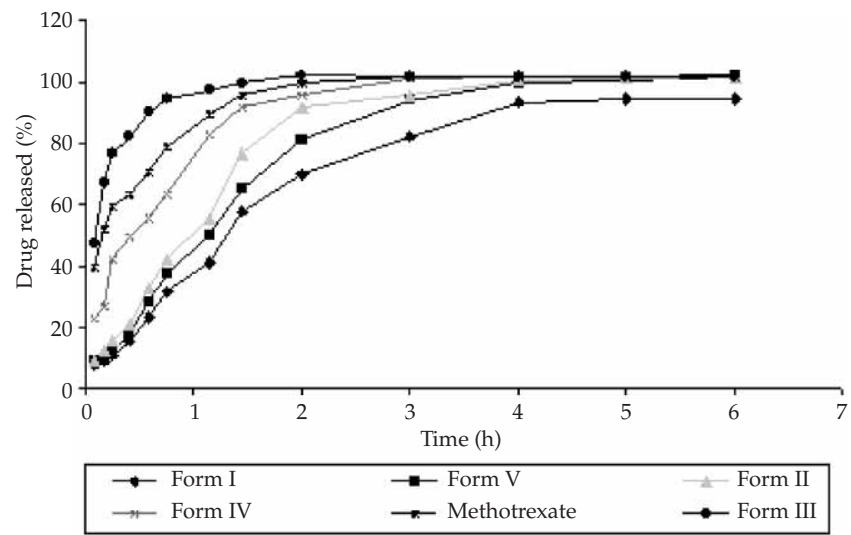

Fig. 6. Dissolution profile of methotrexate and its various forms in $0.1 \mathrm{~mol} \mathrm{~L}^{-1} \mathrm{HCl}$ at $37^{\circ} \mathrm{C}(n=2)$. 
R. Chadha et al.: Characterization of solvatomorphs of methotrexate using thermoanalytical and other techniques, Acta Pharm. 59 (2009) 245-247.

\section{Dissolution study}

The dissolution profiles of the different forms are compared in Fig. 6. The dissolution rate of the least crystalline form (form III) was significantly higher than any other form while the dissolution rate of form I was the lowest. These results are also in agreement with the enthalpy of solution, solubility, XRPD and other studies.

\section{CONCLUSIONS}

The present study has showed that the nature of the solvent modifies the crystal form of methotrexate, leading to three solvatomorphs and one partially crystalline form. The commercial sample was found to be a trihydrate. The acetonitrile solvate was found to be the most crystalline among all forms while the form obtained from methanol was found to be partially crystalline. The success of the results depended on the use of solution calorimetry by determining the enthalpy of solution of all forms. The forms were found to be endothermic but the magnitude decreased in the following order: form I > form V $>$ form II $\geq$ form IV $\geq$ commercial sample $>$ form III. The solubility and dissolution study followed the same trend, indicating that form III was the least endothermic, most soluble and had the highest rate of dissolution.

\section{REFERENCES}

1. M. C. Tros de Ilarduya, C. Martin, M. M. Goni and M. C. Martinez-Oharriz, Polymorphism of sulindac: Isolation and characterization of a new polymorph and three new solvates, J. Pharm. Sci. 86 (1997) 248-251; DOI: 10.1021/js9601748.

2. H. G. Brittain, Polymorphism and solvatomorphism 2005, J. Pharm. Sci. 96 (2007) 705-760; DOI: 10.1002/jps.20772.

3. M. R. Yadav, A. R. Shaikh, V. Ganesan, R. Giridhar and R. Chadha, Studies on the crystal forms of pefloxacin: Preparation, characterization and dissolution profile, J. Pharm. Sci. 97 (2007) 2637-2648; DOI: $10.1002 / j p s .21178$.

4. E. Swanepoel, W. Liebenberg and M. M. de Villiers, Quality evaluation of generic drugs by dissolution test: changing the USP dissolution medium to distinguish between active and non-active mebendazole polymorphs, Eur. J. Pharm. Biopharm. 55 (2003) 345-349; DOI: 10.1016/S0939-6411(03)00004-3.

5. S. Ghodbane and J. A. McCauley, Study of polymorphism of 3-((3-(2-(7-chloro-2-quinolinyl)-(E)-ethenyl)phenyl)((3-(dimethylamino-3-oxopropyl)thio)methyl)-thio) propanoic acid (MK571) by DSC, TG, XRPD and solubility measurements, Int. J. Pharm. 59 (1990) 281-286; DOI: 10.1016/0378-5173(90)90119-O.

6. D. Giron, C. Goldbronn, M. Mutz, S. Pfeffer, P. Piechon and P. Schwab, Solid state characterizations of pharmaceutical hydrates, J. Therm. Anal. 68 (2002) 453-465.

7. B. K. Saha, A. Nangia and M. Jaskolski, Crystal engineering with hydrogen bonds and halogen bonds, Cryst. Eng. Comm. 7 (2005) 355-358; DOI: 10.1039/b501693b.

8. Martindale, The Complete Drug Reference, $34^{\text {th }}$ ed., Pharmaceutical Press, London 2005, p. 553.

9. H. K. Chan and I. Gonda, Methotrexate: Existence of different types of solid, Int. J. Pharm. 68 (1991) 179-190. 
R. Chadha et al.: Characterization of solvatomorphs of methotrexate using thermoanalytical and other techniques, Acta Pharm. 59 (2009) 245-247.

10. K. Urakami, Characterization of pharmaceutical polymorphs by isothermal calorimetry, Curr. Pharm. Biotech. 6 (2005) 193-203; DOI: 10.2174/1389201054022904.

11. H. G. Brittain, Spectral methods for the characterization of polymorphs and solvates, J. Pharm. Sci. 86 (1997) 405-412; DOI: 10.1021/js960238e.

12. D. Giron, Investigations of polymorphism and pseudo-polymorphism in pharmaceuticals by combined thermoanalytical techniques, J. Therm. Anal. 64 (2001) 37-60.

13. J. Bauer, J. Morley, S. Spanton, F. J. J. Leusen, R. Henry, S. Hollis, W. Heitmann, A. Mannino, J. Quick and W. Dziki, Identification, preparation and characterization of several polymorphs and solvates of terazosin hydrochloride, J. Pharm. Sci. 95 (2006) 917-928.

14. G. W. Lu, M. Hawley, M. Smith, B. M. Geiger and W. Pfund, Characterization of a novel polymorphic form of celecoxib, J. Pharm. Sci. 95 (2006) 305-317; DOI: 10.1002/jps.20522.

15. A. Othman, J. S. O. Evans, I. R. Evans and R. K. Harris, Structural study of polymorphs and solvates of finasteride, J. Pharm. Sci. 96 (2007) 1380-1397; DOI: 10.1002/jps.20940.

16. M. R. Caira, G. Bettinetti, M. Sorrenti and L. Catenacci, Relationships between structural and thermal properties of anhydrous and solvated crystalline forms of brodimoprim, J. Pharm. Sci. 96 (2007) 996-1007; DOI: 10.1002/jps.20934.

17. M. Sheikhzadeh, S. Rohani, A. Jutan and T. Manifar, Quantitative and molecular analysis of buspirone hydrochloride polymorphs, J. Pharm. Sci. 96 (2007) 569-583; DOI: 10.1002/jps.20723.

18. G. D. Christian, Acid-base Equilibria, in Analytical Chemistry, $6^{\text {th }}$ ed., John Wiley, Singapore 2004, pp. 253-254.

19. P. Balk and G. C. Benson, Calorimetric determination of the surface enthalpy of potassium chloride, J. Phys. Chem. 63 (1959) 1009-1012.

20. USP 27, NF 22, USP Convention Inc., Rockville (MD) 2004, pp. 2303-2304.

21. P. A. Sutton, V. Cody and G. D. Smith, Crystal structure of methotrexate tetrahydrate, J. Am. Chem. Soc. 108 (1986) 4155-4158; DOI: 10.1021/ja00274a051.

22. T. W. Hambley, H. K. Chan and I. Gonda, Crystal and molecular structure of methotrexate, J. Am. Chem. Soc. 108 (1986) 2103-2105; DOI: 10.1021/ja00268a068.

23. M. R. Caira, G. Bettinetti and M. Sorrenti, Structural relationships, thermal properties and physicochemical characterization of anhydrous and solvated crystalline forms of tetroxoprim, J. Pharm. Sci. 91 (2002) 467-481; DOI: 10.1002/jps.10034.

24. K. Terada, H. Kitano, Y. Yoshihashi and E. Yonemochi, Quantitative correlation between initial dissolution rate and heat of solution, Pharm. Res. 17 (2008) 920-924.

25. I. P. Dominic, B. S. Gerald, J. M. Stevenson, S. Lindenbaum, A. W. Douglas, S. D. Klein and J. A. McCauley, High resolution spectroscopic evidence and solution calorimetry studies on the polymorphs of enalapril maleate, Int. J. Pharm. 28 (1986) 183-191.

\section{$S A \check{Z} E T A K$}

\section{Karakterizacija solvatomorfa metotreksata pomoću termoanalitičkih i drugih metoda}

RENU CHADHA, POONAM ARORA, RUPINDER KAUR, ANUPAM SAINI, MADAN LAL SINGLA i DHARAMVIR SINGH JAIN

U radu je provedena identifikacija i karakterizacija pet različitih formi metotreksata dobivenih kristalizacijom iz različitih otapala. Desolvatacijska izoterma u DSC popraćena gubitkom mase u TGA za forme I, II, IV i V ukazuje da su te forme solvati s aceto- 
R. Chadha et al.: Characterization of solvatomorphs of methotrexate using thermoanalytical and other techniques, Acta Pharm. 59 (2009) 245-247.

nitrilom: hidrat (forma I), trihidrat (forma II i IV) i solvat s dimetilformamidom (forma V). Međutim, desolvatacijski pik je odsutan u formi III (dobivenoj iz metanola) što ukazuje na odsutnost otapala u kristalnoj formi. Ta forma je parcijalno kristalna i pokazuje odgovarajući XRPD uzorak. Energija kristalne ćelije je za različite forme različita, što ima za posljedicu različite entalpije otapanja te omogućava primjenu kalorimetrije otopine za diferencijaciju formi. Topljivost je korelirana s entalpijom otopine i kristaliničnosti svih formi. Najmanje endotermna forma (forma III) je najbolje topljiva.

Ključne riječi: solvatomorf, pseudopolimorf, metotreksat, entalija otopine, kalorimetrija otopine, desolvatacija, topljivost

University Institute of Pharmaceutical Sciences, Panjab University, Chandigarh-160014, India

Central Scientific Instruments Organization, Sector-30/C, Chandigarh-16003, India

Department of Chemistry, Panjab University, Chandigarh-160014, India 